\title{
BODY OF THE CRIME AS A SYSTEM
}

\author{
Elena V. Shchelkonogova \\ Ural State Law University, Yekaterinburg, Russian Federation
}

Introduction: body of the crime is of paramount importance not only as a statutory concept in the Russian criminal legislation, but also as a tool to determine that an act is a crime, due to what the author of the criminal law study set the goal of researching the body of the crime as a system. Methods: the methodological framework for this study is a set of methods of scientific knowledge, among which the main ones are the methods of historicism, systematicity, analysis and comparative law. Results: the author's well-founded position is based on the legislation and the opinions of the competent scientific community of the question of why the body of crime is a system. Based on the legal analysis of the theory of law provisions, the differentiation of characteristic features of the body of the crime as a statutory concept is carried out. The issues of legal regulation of various types of crimes are raised by using the system properties of the body of the crime. Conclusions: as a result of the study, the role of the body of the crime as a statutory concept for the further development of the Russian legislation was identified, and the features that allow us to speak of it as a system were identified. It is established that the body of the crime is a natural result of the development and improvement of those provisions that were laid down in the criminal legislation.

Key words: system approach, classification of crime, body of the crime, crime, Special Part of the Criminal Code of the Russian Federation.

Citation. Shchelkonogova E.V. Body of the Crime as a System. Legal Concept, 2020, vol. 19, no. 1, pp. 146-150. (in Russian). DOI: https://doi.org/10.15688/lc.jvolsu.2020.1.21

УДК 34.343 .01

ББК 67.408
Дата поступления статьи: 02.12.2019

Дата принятия статьи: 12.01.2020

\section{СОСТАВ ПРЕСТУПЛЕНИЯ КАК СИСТЕМА}

\section{Елена Владимировна Щелконогова}

Уральский государственный юридический университет, г. Екатеринбург, Российская Федерация

Введение: состав преступления имеет крайне важное значение не только как юридическая конструкция в российском уголовном законодательстве, но и как инструмент определения того, что какое-либо деяние является преступлением, в связи с чем автором в работе уголовно-правового характера поставлена цель исследования состава преступления в качестве системы. Методы: методологическую основу данного исследования составляет совокупность методов научного познания, среди которых основное место занимают методы историзма, системности, анализа и сравнительно-правовой. Результаты: обоснованная в работе авторская позиция опирается на законодательство и мнения компетентной научной среды по вопросу о том, почему состав преступления является системой. На основании правового анализа положений теории права проводится дифференциация характерных признаков состава преступления как юридической конструкции. Поднимаются вопросы правовой регламентации различных видов преступлений с помощью системных свойств состава преступления. Выводы: в результате исследования выявлена роль состава преступления как юридической конструкции для дальнейшего развития российского законодательства, определены признаки, позволяющие говорить о нем как о системе. Установлено, что состав преступления является закономерным результатом развития и совершенствования тех положений, которые были заложены в уголовном законодательстве.

Ключевые слова: системный подход, квалификация, состав преступления, преступление, Особенная часть УК РФ. 
Цитирование. Щелконогова Е. В. Состав преступления как система // Legal Concept = Правовая парадигмa.-2020. - Т. 19, № 1. -C. 146-150. - DOI: https://doi.org/10.15688/lc.jvolsu.2020.1.21

\section{Введение}

Категория состава преступления является одной из самых ключевых дефиниций уголовного права, поскольку именно от наличия состава зависит то, будет ли оценено правоприменителем совершенное виновным деяние в качестве преступления или нет. Несмотря на свою значимость термин «состав преступления» упоминается в уголовном кодексе лишь единожды в ст. 8, в которой говорится об основаниях привлечения к уголовной ответственности. Актуальность исследования состава преступления как логической конструкции представляется существенной в свете того, что квалификация преступления должна быть справедливой. Применяя статьи уголовного кодекса, необходимо учитывать, чтобы выбранный состав преступления наиболее точно отражал признаки деяния, совершенного в объективной действительности. Если же такое условие отсутствует, то говорить о наличии преступления невозможно, так как в отличие от иных отраслей права, в уголовном праве запрещена как аналогия права, так и аналогия закона.

Изучение состава преступления возможно с применением системного подхода, так как любой объект можно рассматривать с точки зрения системы. Система как философская категория предполагает наличие элементов, ее образующих. В отличие от классификации или структуры, система характеризуется логическими взаимосвязями своих частей, то есть каждый из составных элементов не только несет свою смысловую нагрузку, но и дополняет остальные, наполняет объект определенным смыслом. Эти признаки являются ключевыми в системе.

\section{Юридическая природа категории «состав преступления»}

Первые упоминания о составе преступления в российском уголовном праве относятся к XVI в., однако вплоть до конца XIX в. под составом преступления (лат. corpus delicti) понимаются вещественные свидетельства совершения преступления [8, с. 133]. В мировой истории развития уголовного законодательства некий прототип состава преступления был выработан еще римскими юристами, которые определили схему, включающую семь основных пунктов: кто совершил, что именно (какое преступление), где (место совершения преступления), когда (время совершения), с какой помощью, каким образом (способ совершения), с чьей помощью [6, с. 105108]. В современном уголовном праве понятие «состав преступления» является преимущественно доктринальным, а не законодательным. Уголовные кодексы большинства государств не используют данную правовую категорию, не применяется она и в англо-американском прецедентном праве [4, с. 166].

Поскольку в статье ставится цель рассмотреть состав преступления с точки зрения системного подхода, то логично поставить вопрос: является ли состав преступления системой? То есть установить: верно ли, что под составом преступления подразумевают четыре элемента, насколько целесообразно их выделение. Современными учеными при описании состава преступления в первую очередь делается акцент преимущественно на его объективных и субъективных признаках [10, c. 66]. С философской точки зрения объективность - это принадлежность объекту, независимость от субъекта. Если опираться на данное определение, то можно сделать вывод, что объект и объективная сторона состава преступления не зависят от субъекта, от его воли и желания. Но объективная сторона не может не зависеть от воли субъекта, поскольку она совершается субъектом.

В дореволюционной литературе ученые к составу преступления относили: субъекта, объект, противоправность и виновность деяния [7, с. 50]. То есть такие признаки, как противоправность и виновность относились тогда к признакам состава преступления, а не понятия преступления, как сейчас. Современное строение состава преступления разрабатывалось в советский период времени [9, 
c. 59-60]. «Руководящие начала», характеризуя принципы состава преступления, делали акцент на объекте преступления [5, с. 77].

Если в XIX в. отечественные криминалисты придерживались нормативной теории и рассматривали в качестве объекта преступления юридическую норму в ее реальном бытии, то советские ученые определяли объект преступления как совокупность общественных отношений. Эта теория до последнего времени сохраняла свое преимущество в доктрине. Некоторыми авторами предлагается в качестве объекта «признать те блага, на которые посягает преступное деяние» [3, c. 169]. Ведя речь о системе состава преступления, ученые ставят вопрос об исключении элементов из него.

Ученые отмечают единство и взаимосвязь элементов состава преступления. Можно ли говорить о том, что признаки состава формулируются в уголовном законе в статьях Особенной части УК [10, с. 68], ведь правовая норма описывается в статьях обеих частей? Каждая из статей Особенной части будет полноценной только если она будет дополнена каждой из статей Общей части. В Общую часть статьи выделены законодателем для удобства использования, подчеркивается, что они актуальны для каждой статьи Особенной части. Многими авторами поддерживается идея о том, что гипотеза уголовно-правовой нормы содержится не в Особенной, а в ст. 8 Общей части, повествующей как раз о наличии в деянии состава преступления.

Согласно теории права деяния относятся к классификации юридических фактов. Деяния - это жизненные обстоятельства, происходящие по воле людей. Совокупность юридических фактов называют юридическим составом. Исходя из указанных определений, только деяние и субъективная сторона относятся к юридическому составу, а объект и субъект находятся вне его рамок. Следовательно, не все элементы, входящие в состав преступления, соотносятся с тем, что должно относиться к юридическому составу, если отождествлять эти понятия согласно их названиям.

Теория права указывает, что деяние - это жизненные обстоятельства, но в уголовном праве они больше относятся к понятию пре- ступления, которое не тождественно понятию состава преступления. В частности, в учебнике под редакцией О.С. Капинус отмечается, что следует различать понятия преступления и его состава, которые соотносятся между собой как явление и юридическое понятие о нем [11, с. 164]. В уголовном праве деяние является родовым признаком преступления, которое характеризуется общественной опасностью, виновностью, а в теории права деяние - это действие или бездействие, совершенное в реальной жизни. В уголовном праве состав преступления состоит из четырех элементов, а в теории права юридический состав состоит в том числе из деяний, но не содержит таких элементов, как объект и субъект.

Понимание системы состава преступления имеет крайне важное значение при квалификации деяния в свете соблюдения принципа справедливости в уголовном праве. Согласно данному принципу никто не может нести ответственность дважды за одно и то же преступление. То есть квалифицирующие признаки должны быть учтены при оценке преступления только единожды. В правоприменительной практике возникают ситуации, когда признаков, закрепленных в одном составе, недостаточно для описания всех особенностей преступления, в таком случае возникает совокупность преступлений, вменяется несколько составов. Однако необходимость их включения в квалификацию выглядит не всегда однозначной. Например, причинение тяжкого вреда здоровью, повлекшего смерть при разбое, согласно п. 14.1 Постановления Пленума ВС РФ квалифицируется по п. в ч. 4 ст. 162 и ч. 4 ст. 111 УК РФ [12], хотя в ст. 162 уже предусматривается причинение тяжкого вреда здоровью потерпевшего.

Поскольку одним из главных признаков системы является взаимосвязь ее элементов, то с точки зрения наличия данного признака взаимосвязь объекта и субъекта преступления может быть поставлена под сомнение. Если признать, что объект преступления есть общественные отношения, то субъект не взаимодействует с ними, так как его посягательство направлено на предмет или потерпевшего. Если утверждать, что состав преступления - это юридическая конструкция, то не совсем кор- 
ректно выделение в ней субъективных признаков. Состав преступления описывает противоправное деяние, это описание может быть или только объективным, или только субъективным, если считать, что состав преступления это порождение правотворческой деятельности лиц, находящихся под воздействием того или иного исторического периода, политической обстановки, уровня преступности и др. На наш взгляд, термин «субъективные признаки» употребляется при характеристике состава преступления не вполне уместно, так как он больше указывает, что эти признаки не являются универсальными, что они присущи конкретному человеку. Универсальность же признаков необходима, так как российская правовая система не относится к прецедентной.

Ученый В.Н. Кудрявцев утверждает, что «законодатель образует не состав, а уголовно-правовую норму, в которой описываются признаки состава преступления. Сами эти признаки существуют объективно, независимо от сознания людей» [2, с. 46-47]. Однако согласно теории права правовая норма существует вне зависимости от ее законодательного закрепления, в том числе в нормах морали, религии, нравственности, идеологии, поэтому, записывая правовую норму в тексте закона, правотворец лишь придает правовой норме письменный вид, придавая ей при этом обязательную юридическую силу. Если рассматривать состав преступления с философской точки зрения, то можно отметить, что его конструкция строится по диалектическому принципу, то есть в нем объединяется как объективное, так и субъективное. В диалектике противоположности объединяются в своем единстве.

В статье ставится цель рассмотреть состав преступления как систему, поэтому предлагается выявить в нем признаки системы. Безусловно, что любой объект можно рассматривать как систему, поэтому и состав преступления в таком случае не является исключением. Думается, что состав преступления обладает признаками системы: он имеет элементы, образующие его структуру, а также логическую взаимосвязь между ними. Не случайно философ Берталанфи отмечал, что система - это комплекс взаимодействующих компонентов [1, с. 23]. Говоря о взаимосвязи элементов системы, важно отметить, что связь, отношение - это ограничение степени свободы элементов: элементы, вступая во взаимодействие (связь) друг с другом, утрачивают часть свойств или степеней свободы, которыми они потенциально обладали; сама же система как целое при этом приобретает новые свойства. Элементы состава преступления отдельно друг от друга не обладают той функцией, которую они приобретают, объединенные в состав. Согласно ст. 8 УК РФ только при их совокупности можно вести речь о преступлении. И сам состав преступления не имеет смысла и значения без какого-либо из указанных элементов. Следовательно, состав преступления при условии наличия всех своих элементов приобретает новые свойства, получает юридическую значимость. Таким образом, между элементами состава преступления имеется логическая взаимосвязь, позволяющая говорить о наличии в составе преступления признаков системы.

\section{Заключение}

Исходя из изложенного можно утверждать, что категория состава преступления имеет давнюю историю в уголовном законодательстве, ее несомненная роль обусловлена тем, что благодаря этой юридической конструкции упорядочивается механизм признания деяния преступным, учитываются его индивидуальные признаки. Состав преступления обладает признаками системы, так как все его элементы взаимосвязаны между собой и при их единстве он может функционировать. Представление состава преступления как системы важно и для устранения повторной квалификации одних и тех же признаков на практике.

\section{СПИСОК ЛИТЕРАТУРЫ}

1. Берталанфи, Л. фон. Общая теория систем: критический обзор / Л. фон. Берталанфи. - М. : Прогресс, 1969. - 520 с.

2. Кудрявцев, В. Н. Объективная сторона преступления / В. Н. Кудрявцев. - М. : Госюриздат, $1960 .-244 \mathrm{c}$.

3. Курс российского уголовного права / под ред. В. Н. Кудрявцева, А. В. Наумова. - М. : Спарк, 2001. $-767 \mathrm{c}$. 


\section{ПРОТИВОДЕЙСТВИЕ ПРЕСТУПНОСТИ}

4. Курс уголовного права. Т. 1 / под ред. Н. Ф. Кузнецовой. - М., 2002. - 624 с.

5. Ленин, В. И. Сочинения. Т. І / В. И. Ленин. M., 1967. $-569 \mathrm{c}$.

6. Лоба, В. Е. К истории развития понятия «состав преступления» (1581-1917) / В. Е. Лоба, Е. В. Сафронова // Юристъ-Правоведъ. - 2014. № 3. - C. 105-108.

7. Познышев, С. В. Учебник уголовного права / С. В. Познышев. - М. : Юрид. изд-во Наркомюста, 1923. $-296 \mathrm{c}$.

8. Российское уголовное право / под ред. В. С. Комиссарова. - СПб. : Питер, 2005. - 560 с.

9. Трайнин, А. Н. Общее учение о составе преступления / А. Н. Трайнин. - М. : Госюриздат, 1957. $-364 \mathrm{c}$.

10. Уголовное право / отв. ред. А. В. Наумов. М. : Юрайт, 2019. - 411 с.

11. Уголовное право России / под ред. О. С. Капинус. - М. : Юрайт, 2019. - 705 с.

12. УК РФ. Постановление Пленума Верховного Суда РФ «О судебной практике по делам о краже, грабеже и разбое» от 27.12.2002 № 29 // Российская газета. - 2003. - 18 янв. (№ 9).

\section{REFERENCES}

1. Bertalanfi L. fon. Obshchaya teoriya sistem: kriticheskiy obzor [General Theory of Systems: A Critical Review]. Moscow, Progress Publ., 1969. 520 p.

2. Kudryavtsev V.N. Obyektivnaya storona prestupleniya [The Objective Side of the Crime]. Moscow, Gosyurizdat, 1960. 244 p.
3. Kudryavtseva V.N., Naumova A.V., ed. Kurs rossiyskogo ugolovnogo prava [Course of Russian Criminal Law]. Moscow, Spark Publ., 2001. 767 p.

4. Kuznetsova N.F., ed. Kurs ugolovnogo prava. T. 1 [The Course of Criminal Law. Vol. 1]. Moscow, 2002. 624 p.

5. Lenin V.I. Sochineniya. T. I [Lenin V.I. Op., Vol. I]. Moscow, 1967. 569 p.

6. Loba V.E., Safronova E.V. K istorii razvitiya ponyatiya «sostav prestupleniya» (1581-1917) [On the History of the Development of the Concept of "Corpus Delicti” (1581-1917)]. Yurist-Pravoved, 2014, no. 3, pp. 105-108.

7. Poznyshev S.V. Uchebnik ugolovnogo prava [Textbook of Criminal Law]. Moscow, Yurid. izd-vo Narkomyusta, 1923. 296 p.

8. Komissarov V.S., ed. Rossiyskoye ugolovnoye pravo [Russian Criminal Law]. Saint Petersburg, Piter Publ., 2005. 560 p.

9. Traynin A.N. Obshcheye ucheniye o sostave prestupleniya [General Doctrine of the Crime]. Moscow, Gosyurizdat, 1957. 364 p.

10. NaumovA.V., ed. Ugolovnoye pravo [Criminal Law]. Moscow, Yurayt Publ., 2019. 411 p.

11. Kapinus O.S., ed. Ugolovnoye pravo Rossii [The Criminal LawofRussia]. Moscow, Yurayt Publ., 2019.705 p.

12. UK RF. Postanovlenie Plenuma Verkhovnogo Suda RF «O sudebnoy praktike po delam o krazhe, grabezhe i razboe» ot 27.12.2002 № 29 [Criminal Code of the Russian Federation. Resolution of the Plenum of the Supreme Court of the Russian Federation "On Judicial Practice in Cases of Theft, Robbery and Brigandage" Dated December 27, 2002 no. 29]. Rossiyskaya gazeta, 2003, 18 yanv. (no. 9).

\section{Information About the Author}

Elena V. Shchelkonogova, Candidate of Sciences (Jurisprudence), Associate Professor, Department of Criminal Law, Ural State Law University, Komsomolskaya St., 21, 620137 Yekaterinburg, Russian Federation, uglaw@yandex.ru, shelkonogova-ele@mail.ru, https://orcid.org/0000-0003-4528-2278

\section{Информация об авторе}

Елена Владимировна Щелконогова, кандидат юридических наук, доцент кафедры уголовного права, Уральский государственный юридический университет, ул. Комсомольская, 21, 620137 г. Екатеринбург, Российская Федерация, uglaw@yandex.ru, shelkonogova-ele@mail.ru, https://orcid.org/0000-0003-4528-2278 